\title{
Comparing the Efficacy of two Natural Surfactants, Curosurf and Alveofact, in Treatment of Respiratory Distress Syndrome in Preterm Infants
}

\author{
Manizheh Mostafa Gharehbaghi ${ }^{1 *}$, Sanaz Yasrebi ${ }^{2}$
}

\begin{abstract}
Objective: Surfactant replacement therapy and respiratory support are the corn stones for respiratory distress syndrome treatment. Natural surfactants, which are animal derived, have been considered superior to synthetic ones, but the superior type of natural surfactant is still unknown. This study was conducted to compare the efficacy of two types of natural surfactants, Poractan alfa (Curosurf) and Alveofact, in the treatment of respiratory distress syndrome (RDS).

Materials and Methods: In a randomized clinical trial 130 inborn preterm newborn infants with gestation age less than 32 weeks were randomly allocated to two groups; 66 neonates received Curosurf and 64 infants treated with Alveofact.

Results: Demographic characteristics of infants were similar in two groups' patients. The mean number of surfactant replacement therapy was significantly more in Alveofact group $(1.79 \pm 0.92$ vs. $1.22 \pm 0.48, \mathrm{p}<0.001)$. The remaining on ventilator support through 7 days was noted in 9 infants that all of them was treated with Alveofact, $\mathrm{p}=0.001$. The mean duration of oxygen supplementation and hospital stay were $10.97 \pm 2.21$ and $24.50 \pm 23.85$ days in Alveofact group vs. $7.31 \pm 1.65$ and $25.25 \pm 20.61$ days in Curosurf group, $\mathrm{p}=0.03$ and $\mathrm{p}=0.16$ respectively. The rate of complications was similar among patients in two groups.

Conclusion: Our data demonstrate short term benefit with respect to respiratory support in Curosurf treated patients without significant difference in other consequences till discharge. Future studies with larger number of patients are recommended for determining superior natural surfactant.

Keywords: Alveofact, Curosurf, Preterm Infants, Respiratory Distress Syndrome, Surfactant
\end{abstract}

\section{Introduction}

Respiratory distress syndrome (RDS) is mainly observed in preterm newborn infants. The surfactant production is insufficient in preterm infants that lead to reduced pulmonary compliance, increased surface tension; and increased risk of alveolar collapse (1-3). Surfactant replacement therapy and respiratory support are the corn stones for RDS treatment (4). Two main types of surfactant are natural and synthetic. Natural surfactants, which are animal derived, have been considered superior to synthetic types (5-7).

Numerous trials have compared the efficacy of various natural surfactants including Beractant, Curosurf and Calfactant (8-12). Poractant Alfa (Curosurf) is derived from minced porcine lungs. Alveofact and Beractant (Survanta) are bovine derived.

Trials that compared Curosurf versus Beractant identified no significant difference in outcomes including pneumothorax, and intraventricular hemorrhage (8$10,12,13)$, when the same initial dose $(100 \mathrm{mg} / \mathrm{kg})$ was administered, but significant reduction in mortality and need for re-dosing has been reported in $200 \mathrm{mg} /$ $\mathrm{kg}$ Curosurf dose (11). While the efficacy of surfactant in the prevention and treatment of RDS has been well documented, the superior type of surfactant is still unknown. In our country Curosurf and Aveofact are more available than other natural surfactants. There is limited studies compared Alveofact and Curosurf in management of RDS in preterm infants. We conducted this study to compare the efficacy of these two types of surfactant with respect to short term outcome in the preterm infants.

\section{Materials and Methods \\ Inborn Preterm newborn infants with gestation age of 32 weeks or less who were admitted to the neonatal intensive care unit (NICU) at Alzahra hospital, Tabriz, Iran between 1st January 2012 and 31th December 2012 were enrolled in a randomized clinical trial. Exclusion criteria were major congenital anomalies, birth asphyxia (Apgar score less than 4 at 5 minutes) and gestation age more than 32 weeks.}

Received 15 January 2014, Revised 26 March 2014, Accepted 2 April 2014, Available online 14 April 2014

${ }^{1}$ M.D. Professor of Pediatrics and Neonatology, Pediatric Health Research Center, Tabriz University of Medical Sciences, Tabriz, Iran ${ }^{2}$ Resident of Pediatrics, Tabriz University of Medical Sciences, Tabriz, Iran

*Corresponding Author: Manizheh Mostafa Gharehbaghi, M.D. Pediatric health research center. Tabriz University of Medical Sciences, Tabriz, Iran. Tel: +989144143051, Email: gharehbaghimm@yahoo.com 
Preterm infants of 0 to 6 hours age with signs of RDS were randomly allocated to two groups according random number list. Intra tracheal Alveofact (Boehringer Ingelheim Pharma, Ingelheim, Germany) $100 \mathrm{mg} / \mathrm{kg}$ was administered to one group. The other group was treated with intra tracheal poractantalfa (Curosurf, Chiesi farmaceutici, Italy) at the dose of $200 \mathrm{mg} / \mathrm{kg}$ as rescue therapy. The RDS diagnosis was based on the classic symptoms including need for a fraction of inspired oxygen ( $\mathrm{FiO} 2$ ) more than $30 \%$ to maintain oxygen saturation above $90 \%$, tachypnea, retraction and grunting; and was confirmed by characteristic radiologic pattern which include reduced air content and reticulo-granular pattern of lungs with air bronchogram.

Early initiation of nasal continuous positive airway pressure (NCPAP) immediately after birth is one of the main principles for the treatment of RDS in our hospital. The other main principle is surfactant administration via endotracheal tube with a brief period of ventilation and subsequent extubation and using NCPAP thereafter. This method is referred as INSURE (INtubation, SURfactant, Extubation) which was first described by verder et al. (14). The additional dose of surfactant was administered 12 hours later if the infant still required a FiO2 more than 0.40. Primary outcome was remaining on ventilator support through 7 days of age. Secondary outcome was mortality rate, duration of oxygen dependency and hospitalization days in studied patients. Bronchopulmonary dysplasia (BPD) was defined as oxygen depending at day 28. The severity of BPD was determined based on $\mathrm{FiO} 2$ requirement at 36 weeks post menstrual age. Cranial ultrasound examination was performed at days 5-7 for diagnosis of intra-ventricular hemorrhage by a pediatric radiologist. Pneumothorax was defined as radiologic evidence of air leak that collected in pleural space. Diagnosis of sepsis was based on presence of clinical signs of sepsis accompanied by positive blood culture. Patent ductus arteriosus (PDA) was diagnosed based on clinical signs and confirmed by echocardiography which was done by an expert pediatric cardiologist.

Statistical analyses were performed using the statistical packagefor social sciences(SPSS) version 16.0. Quantitative data were presented as mean \pm standard deviation (SD) and qualitative data as frequency and percent. Independent t-test were used for testing continuous scale data and chi square or Fisher exact test for categorical data. A p value less than 0.05 was considered statistically significant.

\section{Results}

Of the 183 preterm infants receiving surfactant during the one year study period in our hospital, 53 were excluded from the study because of their age at first surfactant administration above 6 hours (23 infants), Apgar score less than 4 at 5 minutes (15 infants), major congenital anomalies (5 patients), refer to other hospital (4 patients); and parent refuse to consent (6 infants). One hundred thirty neonates with mean gestation age of $28.87 \pm 2.21$ week and birth weight of $1359 \pm 526$ gram were enrolled in the study. Sixty six neonates treated with Curosurf and 64 infants received Alveofact. The mean age of infants at surfactant replacement therapy was $5.16 \pm 0.66$ hours. Table 1 demonstrates demographic characteristics of studied patients in two groups.

Fifty three neonates in Curosurf group and 33 infants in Alveofact group received one dose surfactant. The mean number of surfactant replacement was 2.06 \pm 1.27 in studied patients. It was $1.22 \pm 0.48$ in Curosurf group and $1.79 \pm 0.92$ in Alveofact group, $p<0.001$. INSURE method was successful in 62 patients $(93.9 \%)$ in Curosurf group and 52 infants $(81.3 \%)$ in Alveofact group, $\mathrm{p}=0.02$. Remaining on ventilator support through the first 7 days of surfactant administration was noted in nine neonates that all of them were from Alveofact group, $p=0.001$. There was need for supplemental oxygen at first two weeks of life in $49(74.2 \%)$ and 40 infants (62.5\%) in Curosurf and Alveofact groups respectively, $\mathrm{p}=0.18$.

The mean duration of oxygen supplementation was significantly longer in Alveofact group (10.97 \pm 2.21 vs. $7.31 \pm 1.65$ days, $\mathrm{p}=0.03$ ), but the mean duration of hospitalization was similar in two groups $(25.25 \pm 20.61$ and 24.50 \pm 23.85 days in Curosurf and Alveofact group respectively, $\mathrm{p}=0.16$ ). Table 2 shows the

Table 1. Demographic characteristics of patients

\begin{tabular}{|c|c|c|c|}
\hline & $\begin{array}{l}\text { Curosurf group } \\
(n=66)\end{array}$ & $\begin{array}{l}\text { Alveofact group } \\
(n=64)\end{array}$ & P. value \\
\hline Gestational age, wk & $28.53 \pm 1.96$ & $28.20 \pm 2.27$ & 0.20 \\
\hline Birth weight, g & $1350 \pm 555$ & $1283 \pm 430$ & 0.53 \\
\hline \multicolumn{4}{|l|}{ Gender } \\
\hline Male, n (\%) & $37(51.3)$ & $39(48.7)$ & 0.59 \\
\hline \multicolumn{4}{|l|}{ Apgar score } \\
\hline 1 minute & $6.68 \pm 1.80$ & $5.74 \pm 1.69$ & 0.52 \\
\hline 5minute & $8.28 \pm 1.28$ & $7.74 \pm 1.68$ & 0.06 \\
\hline Maternal preeclampsia, n (\%) & $17(25.7)$ & $15(23.4)$ & 0.84 \\
\hline \multicolumn{4}{|l|}{ Route of delivery } \\
\hline Cesarean section, $\mathrm{n}(\%)$ & $49(74.3)$ & $44(68.8)$ & 0.56 \\
\hline Ante-natal corticosteroid therapy, n (\%) & $41(62.1)$ & $34(52.9)$ & 0.37 \\
\hline
\end{tabular}


Table 2. Complications of prematurity in studied patients.

\begin{tabular}{|c|c|c|c|}
\hline & $\begin{array}{c}\text { Curosurf group } \\
(n=66)\end{array}$ & $\begin{array}{c}\text { Alveofact group } \\
(n=64)\end{array}$ & $P$ value \\
\hline Pneumothorax, n (\%) & $3(4.5)$ & $2(3.1)$ & 1 \\
\hline Patent ductus arteriosus, $\mathrm{n}(\%)$ & $5(7.6)$ & $10(15.6)$ & 0.17 \\
\hline Intra-ventricular hemorrhage, n (\%) & $5(7.6)$ & $9(14.1)$ & 0.31 \\
\hline Retinopathy of prematurity, $\mathrm{n}(\%)$ & $1(1.5)$ & $1(1.6)$ & 1 \\
\hline Sepsis, n (\%) & $7(10.6)$ & $9(14.1)$ & 0.69 \\
\hline Bronchopulmonary dysplasia, n (\%) & $8(12.1)$ & $14(21.9)$ & 0.15 \\
\hline Mortality, n (\%) & $7(10.6)$ & $14(21.9)$ & $<0.09$ \\
\hline
\end{tabular}

complications in two groups.

\section{Discussion}

In our study, infants who were treated with Alveofact had significantly more re-dosing surfactant and remaining on ventilator support through first week of life. In agree with our study, Proquitte (15) et al. showed that the incidence of bronchopulmonary dysplasia at day $28, \mathrm{IVH}$, PDA, and pneumothorax were not significantly different between infants treated with Alveofact and Curosurf. In their study, the course of $\mathrm{FiO} 2$, and blood gases were similar in both groups. In our study, infants treated with Alveofact need more respiratory support during first days of hospitalization. Difference in age of infants at first surfactant administration may be clinically and physiologically important. Those infants who received their first surfactant within 3 hour of birth were included in Proquitte study (15). In the Baroutis study, infants were treated at 4 hour and in our study at mean age 5 hour (8). However, in one study of 987 infants with 23-30 weeks, gestational ages (16), 244 patients were treated by surfactant administration within first 15 minutes, that considered as prophylaxis and 721 neonates by surfactant administration at 16-180 minutes (defined as early rescue). The rates of re-dosing and mean total doses of surfactant were similar in both groups despite the different ages at surfactant reception. The mortality and complications were also similar. They used natural surfactants in $90 \%$ of studied patients, but they didn't compare the results according surfactant type (16). It is suspected that the subtype of used natural surfactants may affect the clinical responses.

Hammoud et al. (17) showed improved oxygenation and reduced ventilator requirements at 5 days after Survanta treatment in comparison with Alveofact treated infants. In a study of newborns with RDS who was treated with natural surfactant, measured interfacial physicchemical parameters in tracheal aspirate samples prove better properties of the surfactant proteins (SP-B and SP-C) containing preparations, including Curosurf and Alveofact (18). Alveofact showed a higher surface tension lowering capacity under dynamic conditions. On the other hand, it is showed that Curosurf has higher concentrations of plasmalogens and poly unsaturated fatty acid containing phospholipids (PUFA-PL) in comparison with Alveofact. Plasmalogens and PUFA-PL improve the surface properties of lipid mixtures (19). The incidence of BPD, IVH, sepsis and symptomatic PDA appears unaltered in response to surfactant (20). The incidence of these complications was similar in Curosurf and Alveofact group in our study.

Our findings show some differences in first few days after treatment without significant difference on short term morbidity. The observed difference in ventilator requirements and mortality among patients in our studied patients may be due to lower gestation age and birth weight in Alveofact group, although their difference was not statistically significant with this respect.

\section{Conclusion}

In conclusion, the Alveofact receiving infants had more frequency of surfactant replacement therapy, more rate of remaining on ventilator, and longer oxygen supplementation. The rate of bronchopulmonary dysplasia, intraventricular hemorrhage and pneumothorax were similar among patients treated with Curosurf and Alveofact. Future studies with larger number of patients in different range of gestation age and birth weight are recommended to determine superior natural surfactant.

\section{Ethical issues}

The study was approved by the Ethic committee of Tabriz University of Medical Sciences and written informed parent consent was obtained.

\section{Conflict of interests}

The authors declare that they have no competing interests.

\section{Acknowledgments}

This study was supported by Paediatric Health Research Center and Vice Chancellor for Research, Tabriz University of Medical Sciences. We thank the NICU nurses involved in the care of study infants. We also thank Mrs. KhatibShahidi SH for her valuable helps.

\section{References}

1. Burri PH. Fetal and postnatal development of the lung. Ann Rev Physiol 1984; 46:617-28.

2. Engle WA. American Academy of Pediatrics Committee on fetus and newborns. Surfactant replacement therapy for respiratory distress syndrome in preterm and term neonate. 
Pediatrics 2008; 121: 419-32.

3. Ma CC, Ma S. The role of surfactant in respiratory distress syndrome. Open Respir Med J 2012; 6: 44-53.

4. Fujiwara T, Maeta H, Chida S, Morita T, Watabe Y, Abe T. Artificial surfactant therapy in hyaline-membrane disease. Lancet 1980; 12: 55-9.

5. Halliday HL. Surfactants: past, present and future. J Perinatol 2008; 28: S47-56.

6. Cummings JJ, Holm BA, Hudak ML, Hudak BB, Ferquson WH, Egan EA. A controlled clinical trial comparison of four different surfactant preparations in surfactant deficient preterm lambs. Am Rev Respir Dis 1992; 145: 999-1004.

7. Soll RF, Blanco F. Natural surfactant extract versus synthetic surfactant for neonatal respiratory distress syndrome. Cochrane Database Sys Rev 2001;2: CD000144.

8. Baroutis G, Kaleyias J, Liarou T, Papathoma E, Hatzistamatiou Z, Costalos C. Comparison of three treatment regimens of natural surfactant preparations in neonatal respiratory distress syndrome. Eur J Pediatr 2003; 162: 476-80.

9. Malloy CA, Nicoski P, Muraskas JK. A randomized trial comparing beractant and poractant treatment in neonatal respiratory distress syndrome. Acta Pediatr 2005; 94: 77984.

10. Ramanathan R, Rasmussen MR, Gerstmann DR, Finer N, Sekar K, North American study group. A randomized, multicenter masked comparison trial of poractant alfa (Curosurf) versus beractant (Survanta) in the treatment of respiratory distress syndrome in preterm infants. Am J Perinatol 2004; 21:109-19.

11. Singh N, Hawley KL, Viswanathan K. Efficacy of porcine versus bovine surfactants for preterm newborns with respiratory distress syndrome: systematic review and meta analysis. Pediatrics 2011; 128: e1588-95.

12. Gharehbaghi MM, Sakha HS, Ghojazadeh M, Firoozi F. Complications among premature neonates treated with beractant and poractant alfa. Indian J Pediatr 2010; 77:
751-4.

13. Speer CP, Gefeller O, Groneck P, Laufkotter E, Roll C, HansslerL, et al. Randomized clinical trials of two treatment regimens of natural surfactant preparations in neonatal respiratory distress syndrome. Arch Dis Child Fetal Neonatal Ed 1995; 72: F8-13.

14. Verder H, Agertoft L, Albertsen P, Christensen NC, Curstedt T, Ebesen F, et al. [Surfactant treatment of newborn infants with respiratory distress syndrome primarily treated with nasal continuous positive air pressure. A pilot study]. Ugeskr Laeger 1992;154:2136-9.

15. Proquitte H, Dushe T, Hammer H, Rudiger M, Schmalisch G, Wauer RR. Observational study to compare the clinical efficacy of the natural surfactants Alveofact and Curosurf in treatment of respiratory distress syndrome in premature infants. Respir Med 2007; 101: 169-76.

16. Bevilacqua G, Parmiqiani S; OBSERVES Group. An observational study of surfactant treatment in infants of 2330 weeks, gestation: comparison of prophylaxis and early rescue. J Matern Fetal Neonatal Med 2003; 14: 197-204.

17. Hammoud M, Al-Kazmi N, Alshemmiri M, Talib L, Ranjani VT, Derajan LV, et al. Randomized clinical trial comparing two natural surfactant preparations to treat respiratory distress syndrome. J Matern Fetal Neonatal Med 2004; 15:167-75.

18. Todorov R, Lordanova A, Georgiev GA, Petkova KH, Stoimenova E, Georgieva R, et al. [Biophysical models in investigations of exogenous surfactant activities on the surface tension and their therapeutic effectiveness]. AkushGinekol (Sofiia) 2007;46:29-36.

19. Rudiger M, Tolle A, Meier W, Rustow B. Naturally derived commercial surfactants differ in composition of surfactant lipid and in surface viscosity. Am J Physiol Lung Cell Mol Physiol 2005; 288: L379-383.

20. Jobe AH. Pulmonary surfactant therapy. N Eng J Med 1993; 328: 861-8.

Copyright ( 2014 The Author(s); This is an open-access article distributed under the terms of the Creative Commons Attribution License (http://creativecommons.org/licenses/by/4.0), which permits unrestricted use, distribution, and reproduction in any medium, provided the original work is properly cited. 